\title{
Crane flies (Diptera, Tipuloidea) from southern Neotropical salt marshes: survey with DNA barcoding
}

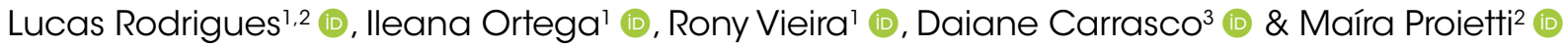

\author{
1. Laboratório de Crustáceos Decápodes, Instituto de Oceanografia, Universidade Federal do Rio Grande - FURG, Av. Itália, Km 8, $96203-000$ Rio Grande, RS, Brazil. \\ (rodrigueslucasweb@gmail.com) \\ 2. Laboratório de Ecologia Molecular Marinha, Instituto de Oceanografia, Universidade Federal do Rio Grande - FURG. \\ 3. Laboratório de Genética, Instituto de Ciências Biológicas, Universidade Federal do Rio Grande - FURG.
}

Received 26 November 2018

Accepted 22 February 2019

Published 28 March 2019

DOI 10.1590/1678-4766e2019013

\begin{abstract}
Crane flies are the most diverse group within Diptera, but they are rarely studied in coastal ecosystems. Considering the scarcity of information on the biology and ecology of this group in the Neotropics, and the sparse literature available for taxonomic identification, we developed a descriptive checklist that incorporates morphology and DNA barcoding. We also created a generic identification key for crane flies of southern Brazilian salt marshes. We sampled crane flies continuously at three areas along the Patos Lagoon salt marshes over one year. A total of 14 genera/subgenera, 6 species, and 12 morphotypes belonging to Limoniidae and Tipulidae were identified. Distribution ranges of Symplecta cana (Walker, 1848) and two Ormosia Rondani, 1856 species were expanded. mtDNA COI sequences were compared to the BOLD and NCBI databases, but were matched only at the family level. Therefore, we provided sequences to both platforms, updated to the genus level. We found low (0.00-0.03) intraspecific and high (0.11-0.25) interspecific molecular differences indicating that the mtDNA COI region is adequate for distinguishing species within the Tipuloidea. The Dicranomyia Stephens, 1829 species complex showed low genetic difference, indicating that they could be one species with high morphological plasticity. This study will serve as a basis for future research on insects of Neotropical salt marshes.
\end{abstract}

KEYWORDS. Barcoding gap, coastal insects, Cytochrome Oxidase I, distribution range.

The superfamily Tipuloidea is the richest within the order Diptera. It is subdivided into Cylindrotomidae, Limoniidae, Pediciidae, and Tipulidae sensu stricto. Approximately 3,500 crane fly species are recognized throughout the Neotropical region, of which around 99.6\% are in the families Limoniidae and Tipulidae (DE JoNG et al., 2008; Oosterbroek, 2018). Crane flies are non-hematophagous flies that are extremely important in the trophic webs they participate in, generally exhibiting a detritivorous diet during their larval phase. Adults generally do not feed, but some will take nectar, and perhaps pollen, and water. The large corporal mass of crane flies, along with their occupation of transitional ecosystems (e.g., salt marshes), make these insects a potential and important trophic link between aquatic and terrestrial environments (e.g., BAXTER et al., 2005). This group is widely distributed over almost all environments, and includes species that occupy wetlands such as salt marshes (Rogers, 1932; AUTIO et al., 2013).

Salt marshes are typical coastal habitats of mid- and high-latitude areas (STEVENs et al., 2006), including the southern Neotropical region. They are characterized as transition areas between estuaries and land, display few but numerous plant species, and are dominated by a fauna and flora that tolerate rapid variations in salinity (COSTA \& MARANGONI, 2010). At Patos Lagoon Estuary, southern
Brazil, estuarine flow and precipitation levels tend to increase salinities at these salt marshes during the summer, and decrease them in the winter (D'INCAO et al., 1992). The margins of this estuarine environment are dominated by halophyte plant species such as Spartina alterniflora and S. densiflora (Poaceae), as well as Myrsine parvifolia (Primulaceae) shrubs (CosTA et al., 1997).

Other than their original descriptions, few studies have reported and updated the occurrence of crane fly species across the Neotropical region (see RIBEIRo et al., 2007; RibEIRO \& SANTOS, 2016). Additionally, research at salt marshes is commonly focused on species such as fish (e.g. CONTENTE et al., 2010; CAMPos et al., 2015), polychaetes, crustaceans (e.g. Mackenzie et al., 2015) and birds (e.g. BRITto \& Bugoni, 2015), but there are rare studies on insect groups conducted at these environments (see GIBERSON et al., 2001; MACKENZIE, 2005; Dummel et al., 2011; Bolico et al., 2012; GANTEs et al., 2013; RoDrigues et al., 2017). In order to support studies on the classification, biogeography, and ecology of these groups, it is necessary to identify the insect species that inhabit these environments, preferably with high taxonomic resolution, as suggested by LENAT \& RESH (2001). Morphological and DNA barcoding methods are frequently combined for taxonomic determination, the latter based mainly on mitochondrial DNA Cytochrome Oxidase Subunit I (COI) sequences for specific 
identification of animals (HeBerT et al., 2004). Therefore, we conducted morphological identification, provided species-specific COI barcode sequences, and developed an identification key for the Tipuloidea genera that occur at salt marshes of the southern Neotropical Region.

\section{MATERIAL AND METHODS}

Study area and sampling. The salt marshes of the Patos Lagoon Estuary are one of the largest in Brazil, covering over $70 \mathrm{~km}^{2}$ (CosTA et al., 1997). We sampled three

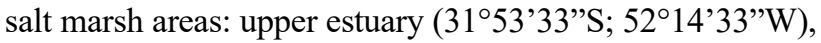
middle estuary ( $\left.32^{\circ} 02^{\prime} 01^{\prime \prime} \mathrm{S} ; 52^{\circ} 10^{\prime} 45^{\prime \prime} \mathrm{W}\right)$, and lower estuary $\left(32^{\circ} 10^{\prime} 65^{\prime \prime} \mathrm{S} ; 52^{\circ} 08^{\prime} 52^{\prime \prime} \mathrm{W}\right)$ (Figure 1). Two Malaise traps with ethanol-filled collection cups were set up at each sampling area, close to the dominant vegetation, for a total of six traps. Malaise traps are flight intercept traps known for efficacy in capturing winged insects, including crane flies. Sampling was conducted continuously over twelve months, from August 2015 to July 2016. Collection cups were changed every 15 days, and collected insects were removed for identification and preservation in $70 \%$ ethanol. Specimens were deposited at the Fundação Zoobotânica do Rio Grande do Sul - FZB/ RS. Sampling was conducted under the Brazilian system for biological sampling (SISBIO) license number 50253-1.

Morphological identification. Genus identification was done using AleXANDer \& Byers (1981) and Gelhaus (2009) based on wing venation and body morphology. When possible, species identification was done using ALEXANDER (1912, 1913, 1962), ANDREW (2000), and StARÝ \& BRODO (2009) based on male genitalia. The morphological terminology adopted here follows MCALPINE (1981).

Species distribution. Large scale species distributions are from the Catalogue of the craneflies of the World
(Oosterbroek, 2018). However, this catalogue does not differentiate between different regions within Brazil, which is important for such a large country with pronounced regional variations.

DNA barcoding. Genomic DNA of approximately three specimens of each morphologically distinct species was extracted through phenol:chlorophorm or salt extraction protocols adapted from SAMBROOK et al. (1989) and ALJANABI \& MARTINEZ (1997), after initial cryogenic grinding with liquid nitrogen. Polymerase Chain Reactions (PCR) were conducted in a Veriti thermocycler to amplify approximately $690 \mathrm{bp}$ of the mitochondrial DNA Cytochrome Oxidase I (COI) gene, using universal primers LCO1490 (5'-GGGTCAACAAATCATAAAGATATTGG-3') and HCO2198 (5'-TAAACTTCAGGGTGACCAAAAAATCA-3') [FolmER et al. (1994)]. The reaction conditions were adapted from PILIPENKo et al. (2012): 4.0 ng DNA; 2.5 U Taq DNA polymerase; 0.4 Mm dNTP mix; $3 \mathrm{Mm} \mathrm{MgCl2}$; and $10 \%$ buffer, in a final volume of $25 \mu \mathrm{l}$. Cycling conditions were $1 \mathrm{~min}$ at $94{ }^{\circ} \mathrm{C}$; 35 cycles of $1 \mathrm{~min}$ at $94{ }^{\circ} \mathrm{C}, 1 \mathrm{~min}$ at $51^{\circ} \mathrm{C}$, and $2 \mathrm{~min}$ at $72{ }^{\circ} \mathrm{C}$; followed by a final extension of $5 \mathrm{~min}$ at $72{ }^{\circ} \mathrm{C}$. Amplified products were purified with Polyethylene Glycol (PEG) 8000 15\% (HARTLEY \& BowEN, 1996) and sequenced in both directions at Macrogen (http://dna.macrogen.com/ eng/). Sequences were visually checked for errors, edited and aligned using BioEdit 7.2.5 (HALL, 1999), and deposited in two online public databases (The Barcode of Life Data System - BOLD - http://www.barcodinglife.org/ and National Center for Biotechnology Information - NCBI - http:// www.ncbi.nlm.nih.gov/Genbank/) with corresponding genus and/or species names. Intra and inter-specific distances were calculated with pairwise genetic distance K2P in MEGA 7, and a histogram created using Barcoding $R$ package available inhttps://github.com/zhangab2008/BarcodingR.
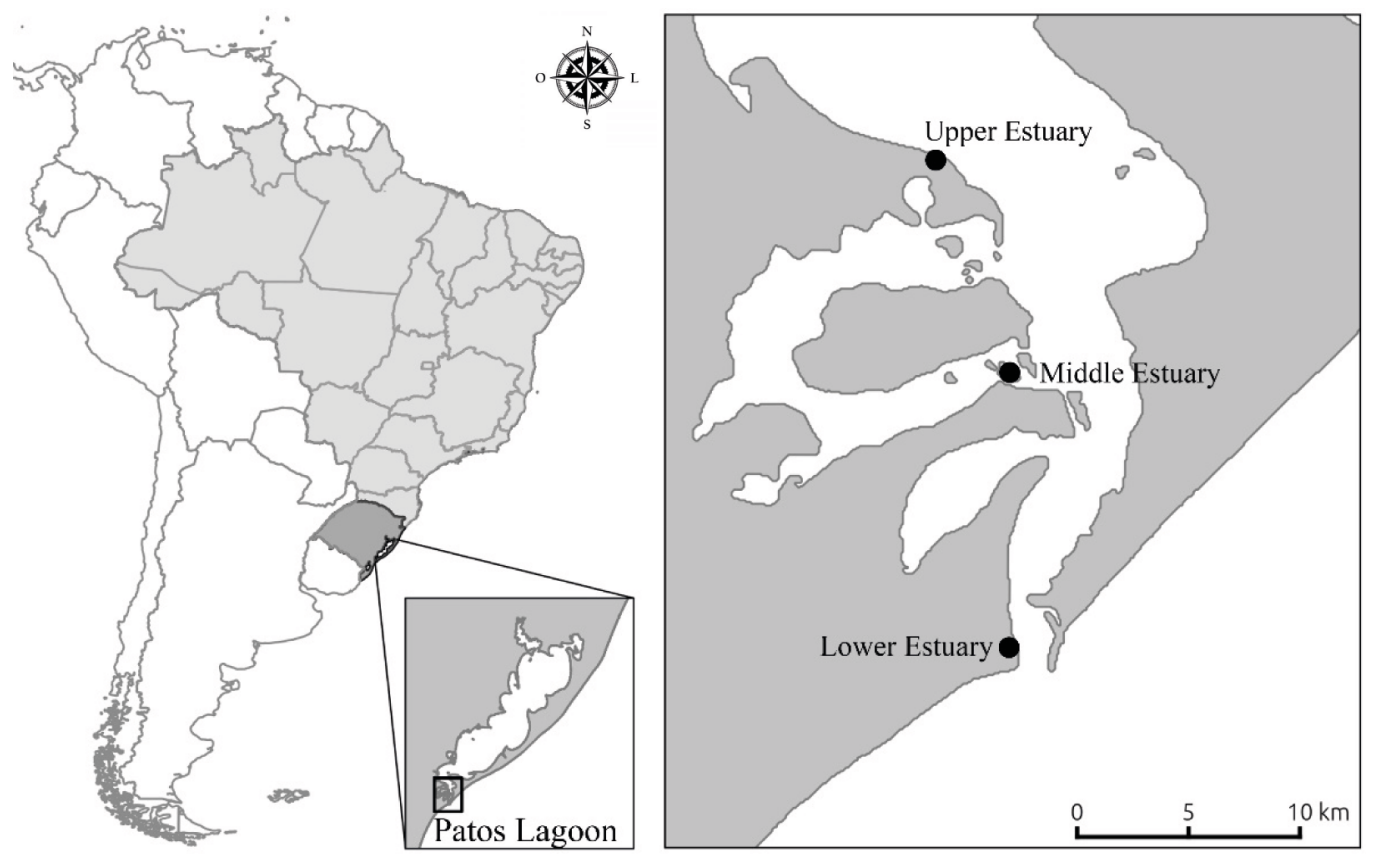

Fig. 1. Sampling areas at salt marshes of the Patos Lagoon Estuary, Rio Grande do Sul, southern Brazil. 


\section{RESULTS}

We collected a total of 5,248 specimens distributed over 18 crane fly species/morphospecies at the salt marshes of Patos Lagoon Estuary. Three species belonged to the family Tipulidae and the other 15 to Limoniidae. This included members of a Dicranomyia species complex. We also found one taxon that we could not identify to genus. Symplecta pilipes (Fabricius, 1787) and Rhipidia domestica amazonensis Osten Sacken, 1860 represented 68\% of all crane flies collected. A total of 43 sequences, corresponding to the 18 species, were compared with those in BOLD. Thirty of these presented $\geq 97 \%$ similarity compared to the existent sequences in the database, but none had specific identification. The majority of these matched sequences are from Argentina, but matches included sequences of Nephrotoma sp. from Ecuador and Geranomyia from the U.S.A., Dominican Republic, and Haiti. All haplotypes of the Dicranomyia complex ( 91.43\%), Gonomyia (Neolipophleps) sp. ( 91.37\%), Polymera inornata Alexander, 1913 ( $~ 88.53 \%)$, P. obscura Macquart, 1838 (88.11\%), and Symplecta cana (95.05\%) showed the lowest similarities with BOLD sequences, and were therefore considered new. We observed overall high interspecific COI differences among Tipuloidea species (between 0.11 and 0.25 ) and low intraspecific differences (between 0.00 and 0.03 ) (Figure 2). Gonomyia (Neolipophleps) sp. was the exception, with intraspecific variation ranging from 0.03 to 0.12 . A checklist of taxa listing their authors, references, and FZB/NCBI deposit numbers is shown in Table 1. It was hard, and in some cases impossible, to identify at specieslevel because C. P. Alexander, whom mostly described them, used mainly coloration or other non-usual taxonomic characters. Geranomyia, Ormosia and the unidentified genus were not included. Three listed species - Ozodicera sp., and the two morphotypes of Toxorhina - did not have enough specimens for molecular analysis. An identification key (modified after GelHaus, 2009) and list of genera/species description is presented below.

\section{Key to Tipuloidea of Patos Lagoon Estuary, Rio Grande do Sul, Brazil}

1. Well-developed rostrum, longer than the remainder of the head, usually with anteriorly projecting and sharply pointed nasus (Fig. 3). ..[Tipulidae] 2 1'. Nasus absent. Rostrum short (Fig. 4), but occasionally lengthened as in Geranomyia and Toxorhina .............................................Limoniidae] 4 2. Flagellomeres 5-10 each with branches (Fig. 5) ...........

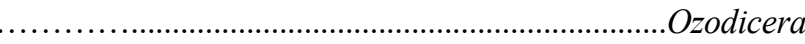
2'. Antennae without branched flagellomeres ...................3 3. Vein Sc ending nearly opposite of origin of Rs; Rs short, oblique; cell dm four-sided with rectangular aspect; bm-cu present (Fig. 6) .................................................Nephrotoma 3'. Vein Sc longer, ending after the origin of Rs; cell dm fivesided, all sides almost equilaterals; bm-cu absent (Fig. 7) ...... Zelandotipula
4. Head with long and slender rostrum and mouthparts, greatly exceeding length of head, usually half of body length or more (Figs 8, 9) ....

4'. Head with non-elongated rostrum and mouthparts; maximum length little more than length of head (Fig. 10)

.

5. Mouthparts fused (Fig. 8)...........................Toxorhina

5'. Mouthparts not fused (Fig. 9) ......................Geranomyia

6. Rostrum as long as or longer than remainder of head

(Fig. 10) .Teucholabis

6'. Rostrum inconspicuous or absent ............................... 7

7. Antennae of males as long as or larger than the entire body

.................................................................... Polymera

7'. Antennae of males shorter than the entire body ...............8

8. Rs absent (Figs 11, 12) .................................... 9

8'. Rs present (Fig. 13) ........................................10

9. Cell dm absent (Fig. 11) ...........Gonomyia (Neolipophleps)

9'. Cell dm present; apex of $\mathrm{R}_{4+5}$ very close to $\mathrm{M}_{1+2}$ (Fig. 12) ...................................Gonomyia (Paralipophleps)

10. Cell dm absent (Fig. 11) ..........................................11

10'.Celldmpresent(Fig. 12) .................................12

11. $\mathrm{R}_{4}$ and $\mathrm{R}_{5}$ beginning after of bt $\mathrm{CuA}_{1}$ (Fig. 13)

Molophilus

11 '. $\mathrm{R}_{4}$ and $\mathrm{R}_{5}$ beginning nearly opposite origin of $\mathrm{bt}$ $\mathrm{CuA}_{1}$ (Fig. 14) ................................................... Ormosia 12. Antennae with 12 flagellomeres ...............................13

12'. Antennae with 13-14 flagellomeres .......................14 13. Flagellomeres unipectinate or subpectinate (Fig. 15) ...... Rhipidia

13'. Flagellomeres of males and females oval to elongated shape (Fig. 16) ......................................Dicranomyia 14. $\mathrm{A}_{2}$ "S" shaped distally; cell $\mathrm{r}_{3}$ with crossvein (Fig. 17) ...... ............................................Symplecta (Symplecta) 14'. A straight (Fig. 18) ..........................Symplecta (Trimicra)

\section{LIMONIIDAE Speiser, 1909}

\section{Dicranomyia Stephens, 1829}

Diagnosis. Morphology of antennae usually simple, antennae with elongated flagellomeres (Fig. 16). Wings, if well developed, with relatively short $\mathrm{Sc}$ vein, usually ending approximate to the base of Rs or before mid-length of Rs, never reaching the fork of Rs.

\section{Geranomyia Haliday, 1833}

Diagnosis. Its members are characterized by both having a supernumerary crossvein at about midlength of wing cell Sc and the elongate mouthparts of the adult fly (Fig. 9).

\section{Gonomyia (Neolipophleps) Alexander, 1947}

Diagnosis. Two branches of Rs strongly divergent, at least at wing margin. Cell $\mathrm{dm}$ absent. Wing hyaline.

\section{Gonomyia (Paralipophleps) Alexander, 1947}

Diagnosis. Two branches of Rs strongly divergent, at least at wing margin. Cell $\mathrm{dm}$ present. Wing with conspicuous dark-brown pterostigmal spot. 
Tab. I. List of genera/species, deposit numbers, sequence nomenclature, and references of crane flies found in salt marshes of the Patos Lagoon Estuary, Rio Grande do Sul, Brazil. *, According to ChaKrabarty et al. (2013); **, First record in Brazil.

\begin{tabular}{|c|c|c|c|c|}
\hline TAXA & $\begin{array}{c}\text { FZB deposit } \\
\text { number }\end{array}$ & $\begin{array}{c}\text { NCBI deposit } \\
\text { number }\end{array}$ & $\begin{array}{c}\text { GenSeq } \\
\text { nomenclature* }\end{array}$ & References \\
\hline \multicolumn{5}{|l|}{ LIMONIIDAE } \\
\hline Dicranomyia sp. 1 "species complex" & 69853 & $\begin{array}{l}\text { MF176169; } \\
\text { MF176170; } \\
\text { MF176171 }\end{array}$ & genseq-4 & - \\
\hline Dicranomyia sp. 2 & 69856 & $\begin{array}{l}\text { MF176172; } \\
\text { MF176173; } \\
\text { MF176174 }\end{array}$ & genseq-4 & - \\
\hline Geranomyia sp. 1 & 69842 & $\begin{array}{l}\text { MF176175; } \\
\text { MF176176 }\end{array}$ & genseq-4 & - \\
\hline Geranomyia sp. 2 & - & $\begin{array}{l}\text { MF176177; } \\
\text { MF176178; } \\
\text { MF176179 }\end{array}$ & genseq-4 & - \\
\hline Gonomyia (Neolipophleps) sp. & 69854 & $\begin{array}{l}\text { MF176183; } \\
\text { MF176184; } \\
\text { MF176185 }\end{array}$ & genseq-4 & - \\
\hline Gonomyia (Paralipophleps) sp. & 69852 & $\begin{array}{l}\text { MF176180; } \\
\text { MF176181; } \\
\text { MF176182 }\end{array}$ & genseq-4 & - \\
\hline Molophilus sp. & - & - & no classification & - \\
\hline Polymera (Polymera) obscura Macquart, 1838 & 69844 & MF176197 & genseq-4 & ALEXANDER, 1913 \\
\hline Polymera (Polymera) inornata Alexander, 1913** & 69845 & $\begin{array}{l}\text { MF176194; } \\
\text { MF176195; } \\
\text { MF176196 }\end{array}$ & genseq-4 & AleXANDER, 1913 \\
\hline Rhipidia domestica amazonensis Osten Sacken, 1860 & 69843 & $\begin{array}{l}\text { MF176198; } \\
\text { MF176199; } \\
\text { MF176200 }\end{array}$ & genseq-4 & ALEXANDER, 1912 \\
\hline Symplecta (Symplecta) cana (Walker, 1848)** & 69857 & MF176201 & genseq-4 & STÁRY \& BRODO, 2009 \\
\hline Symplecta (Trimicra) pilipes pilipes (Fabricius, 1787) & 69849 & $\begin{array}{l}\text { MF176202; } \\
\text { MF176203; } \\
\text { MF176204 }\end{array}$ & genseq-4 & ANDREW, 2000 \\
\hline Teucholabis (Teucholabis) sp. & 69848 & $\begin{array}{l}\text { MF176205; } \\
\text { MF176206; } \\
\text { MF176207 }\end{array}$ & genseq-4 & - \\
\hline Toxorhina (Toxorhina) sp. 1 & 69855 & - & no classification & - \\
\hline Toxorhina (Toxorhina) sp. 2 & 69846 & - & no classification & - \\
\hline \multicolumn{5}{|l|}{ TIPULIDAE } \\
\hline Nephrotoma sp. & 69847 & $\begin{array}{l}\text { MF176186; } \\
\text { MF176187; } \\
\text { MF176188 }\end{array}$ & genseq-4 & - \\
\hline Ozodicera (Ozodicera) sp. & 69850 & - & no classification & - \\
\hline Zelandotipula neurotrichia (Alexander, 1962)** & 69851 & $\begin{array}{l}\text { MF176210; } \\
\text { MF176211 }\end{array}$ & genseq-4 & ALEXANDER, 1962 \\
\hline
\end{tabular}

\section{Molophilus Curtis, 1833}

Diagnosis. Rs forking into $\mathrm{R}_{2+3}$ and $\mathrm{R}_{4+5}$ while in the other Limoniidae species Rs forks into $\mathrm{R}_{2+3+4}$ and $\mathrm{R}_{5}$.

\section{Polymera Wiedemann, 1821}

Diagnosis. Males with extremely elongated antennae, at least as long as body, and usually clothed with long, delicate, outstretched hairs. Antennal segments elongatecylindrical or bi-nodose.

\section{Polymera obscura Macquart, 1838}

Diagnosis. Antennal segments bi-nodose, darker on the nodes, lighter at the constriction. Wings gray with indistinct rounded clouds at the origin of Rs.
Previous geographical distribution: Argentina, Bolivia, Brazil, Guyana, Mexico, Panama, Peru.

\section{Polymera inornata Alexander, 1913}

Diagnosis. Antennal segments bi-nodose, lighter at the base and apex of each segment, but not producing an annulated effect as in P. obscura. Differs from other species in the extreme recession of the cross-vein $r$ (i.e., $r$ equidistant between tip of $\mathrm{Sc} 2$ and tip of $\mathrm{R}_{1}$ ).

Previous geographical distribution: Guyana.

\section{Rhipidia Meigen, 1818}

Diagnosis. The most important and conspicuous diagnostic feature of the genus is that the male flagellomeres 


\section{DNA barcoding gap analysis}

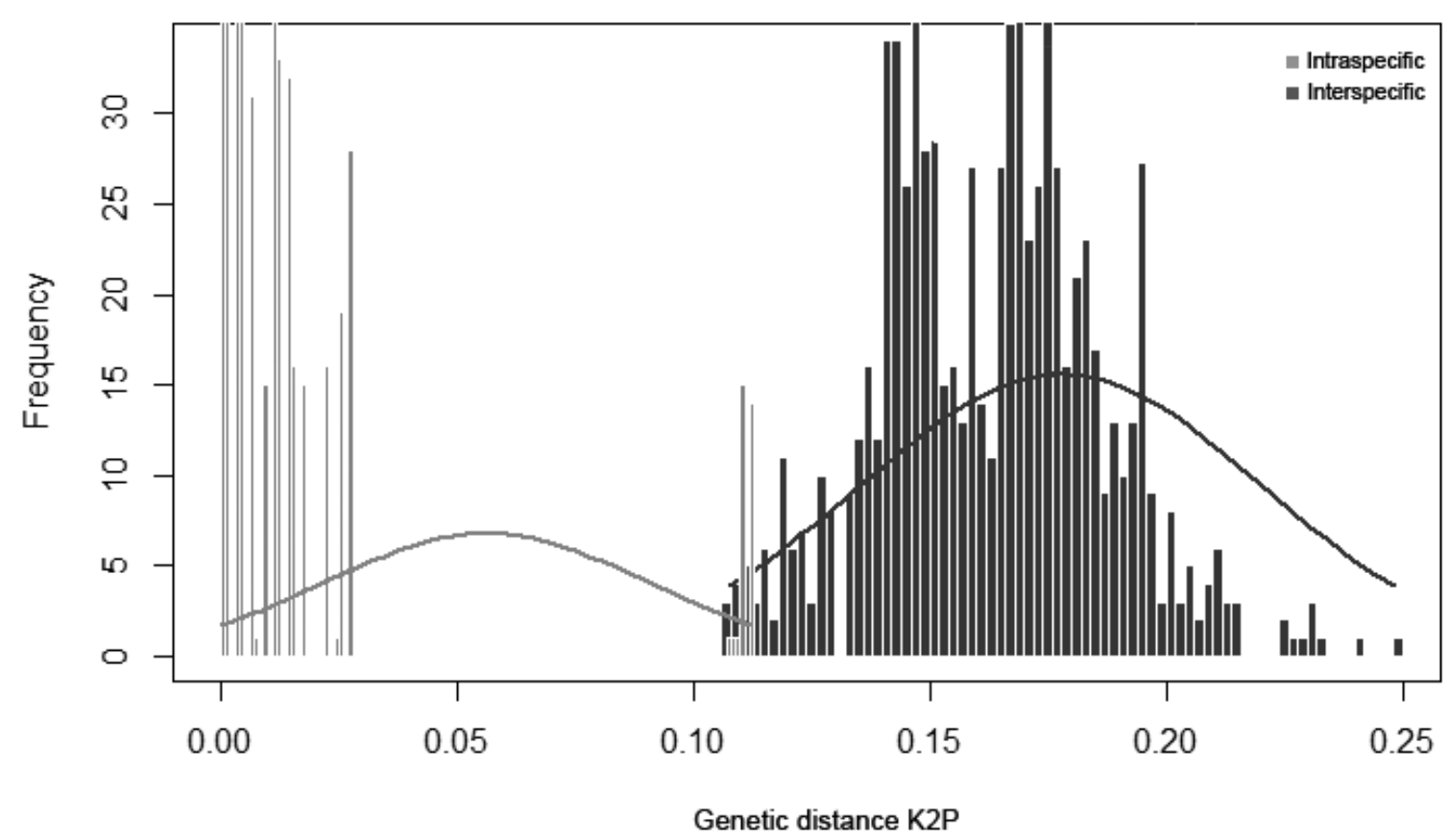

Fig. 2. DNA barcoding gap analysis, with frequency of intra and interspecific distances in COI sequences among Tipuloidea species.

are bipectinate, unipectinate, or subpectinate (Fig. 15).

\section{Rhipidia domestica amazonensis Osten Sacken, 1860}

Diagnosis. Mesotonal praescutum with dark longitudinal lines with wing markings large, scanty, confined to the neighborhood of veins. Wings tinged with brown in $R$. domestica amazonensis compared to the hyaline wings of $R$. domestica domestica.

Previous geographical distribution: East Brazil

\section{Symplecta (Symplecta) Meigen, 1830}

Diagnosis. Wings usually with spots and seams on cross-veins, base of Rs, tips of $\mathrm{Sc}$ and $\mathrm{R}_{1}$, and middle and tip pf $A_{2}$. Supernumerary cross-vein in cell $R_{3}$. $A_{2}$ more or less sinuous (Fig. 17).

\section{Symplecta (Symplecta) cana (Walker, 1848)}

Diagnosis. A "S" shaped distally. The ventral tip of the gonocoxite extended, placing the gonostyli in a subapical position.

Previous geographical distribution. Canada, U.S.A., Guatemala, Mexico.

\section{Symplecta (Trimicra)}

Diagnosis. Subgenera Trimicra is distinguished by the antennae, in which the apical three segments are abruptly slenderer than the preceding ones.

\section{Symplecta (Trimicra) pilipes (Fabricius, 1787)}

Diagnosis. On male, vein Rs with dense row of long hairs. Mainly larger size, unpatterned wings and hairy legs distinguish this species from others in Trimicra.
Previous geographical distribution. The only cosmopolitan species crane fly (ANDREW, 2000).

\section{TIPULIDAE Latreille, 1802}

\section{Zelandotipula Alexander, 1922}

Diagnosis. Wing with cell $r_{3}$ constricted at midlength. Wing often with spot or cloud over origin of Rs, and at base of middle of cell bm.

\section{Zelandotipula neurotrichia (Alexander, 1962)}

Diagnosis. Wings gray, conspicuously patterned with brown, including cord and adjacent veins. Veins beyond cord with conspicuous macrotrichia, including all veins from $\mathrm{R}_{2+3}$ to distal section of vein $\mathrm{Cu}_{1}$. Abdomen with segments conspicuously bicolored, disk yellow and with brown margins.

Previous geographical distribution: Bolivia.

\section{DISCUSSION}

The richness of insects in salt marsh environments is commonly underestimated because of the general assumption that this environment is hostile for insects with aquatic/semiaquatic larval phases. However, previous studies have shown that relatively high salinity does not hinder the presence of Diptera species in these habitats (Williams \& Williams, 1998; Giberson et al., 2001; MACKENZIE, 2005; SILBERBUSH et al., 2005; Borx et al., 2008). This is supported by our results, particularly for the species richness in Limoniidae.

Some of the taxa we identified are noteworthy: Dicranomyia is the largest genus in the Limoniidae, 


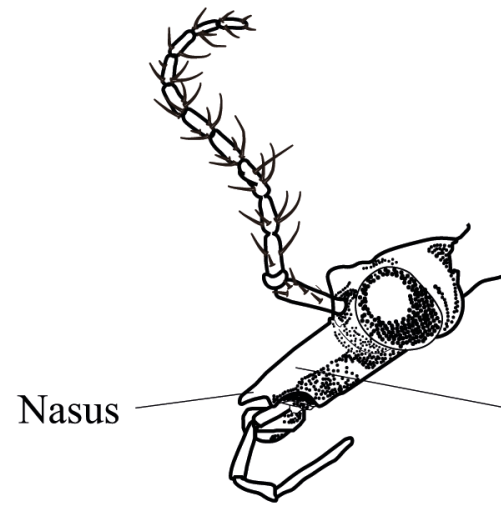

3

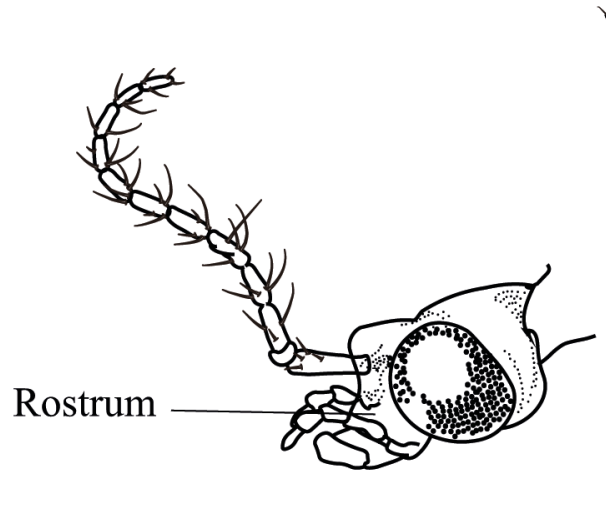

4
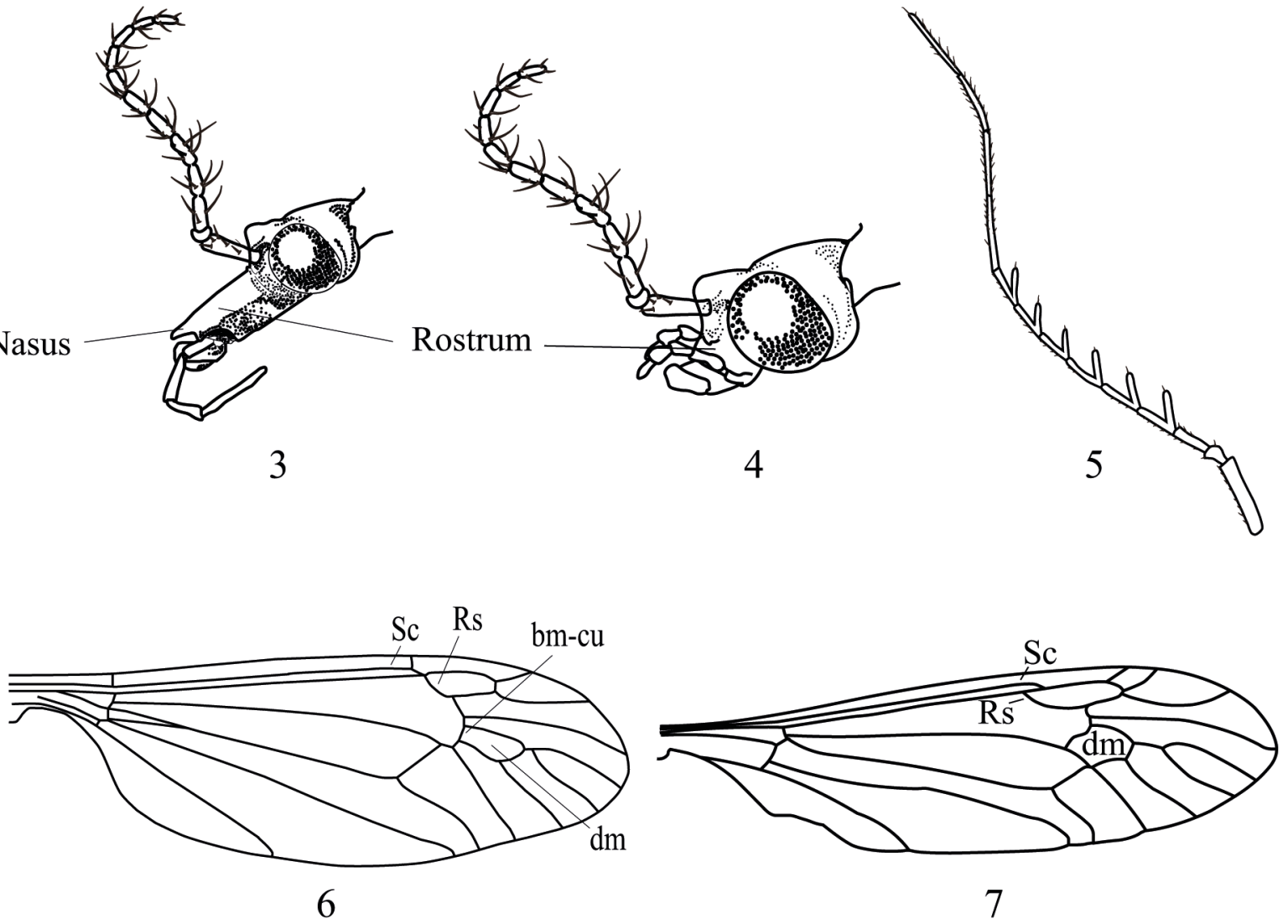

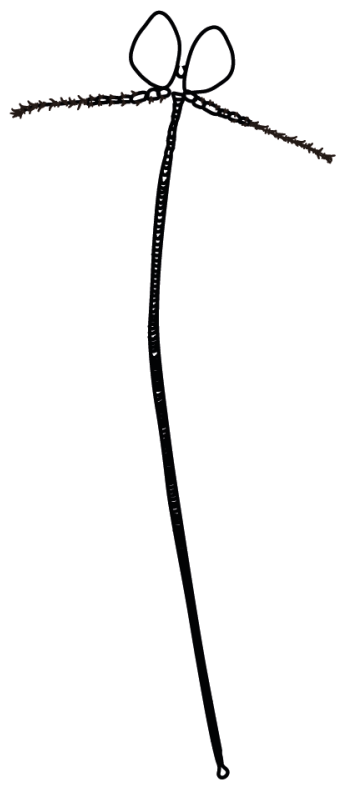

8

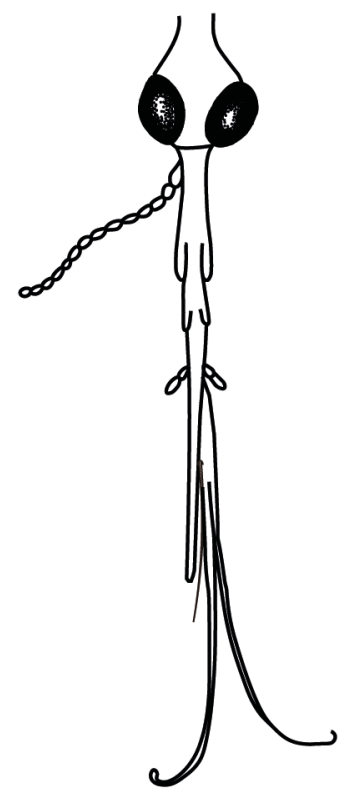

9

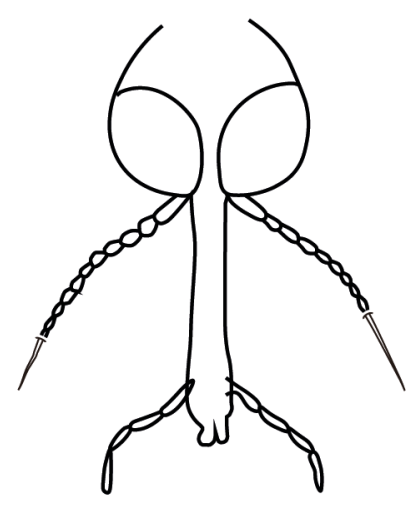

10

Figs 3-10. Morphological characteres for Tipuloidea genera identification: (3) Tipulidae*, (4) Limoniidae, head; (5) Ozodicera*, antennae. (6) Nephrotoma* and (7) Zelandotipula, wings; (8) Toxorhina*, (9) Geranomyia* and (10) Teucholabis*, head (Sc, Subcostal vein; Rs, Radial sector vein; bm-cu, Basalmedial cubital vein; dm, Discal-medial cell). *Modified from GelHaus (2009). 


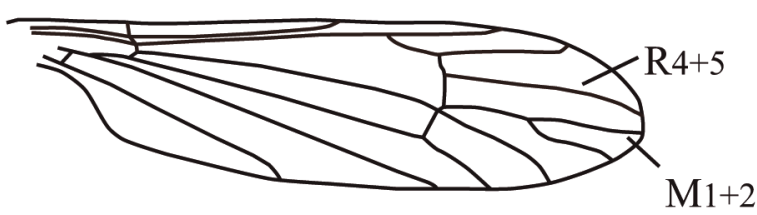

11

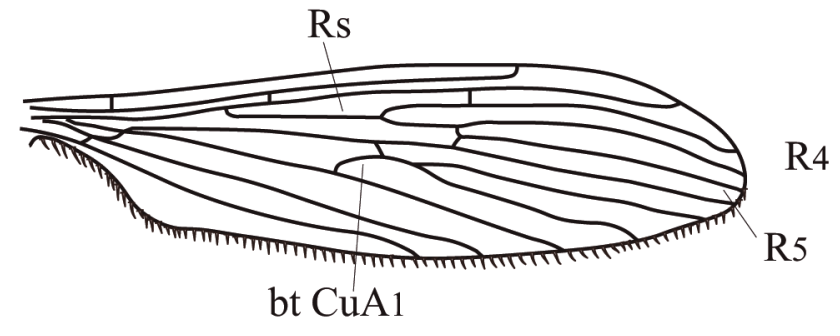

13

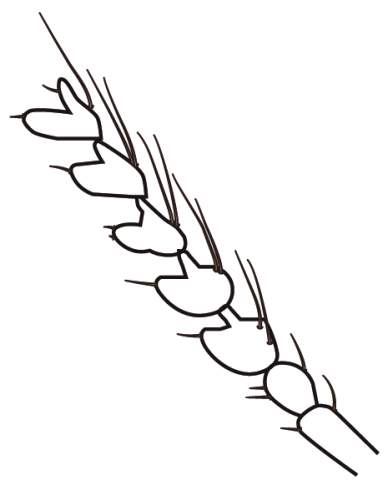

15

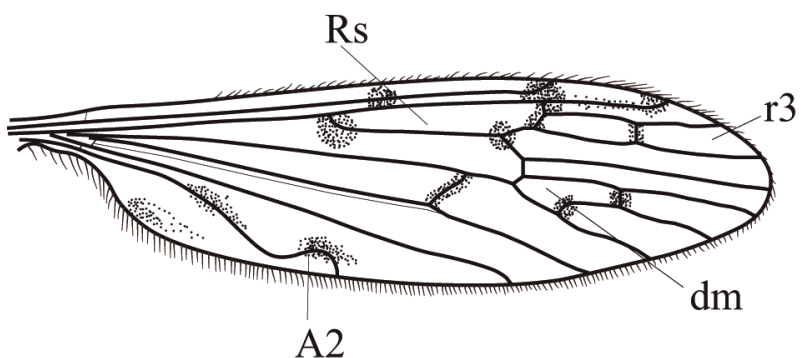

17
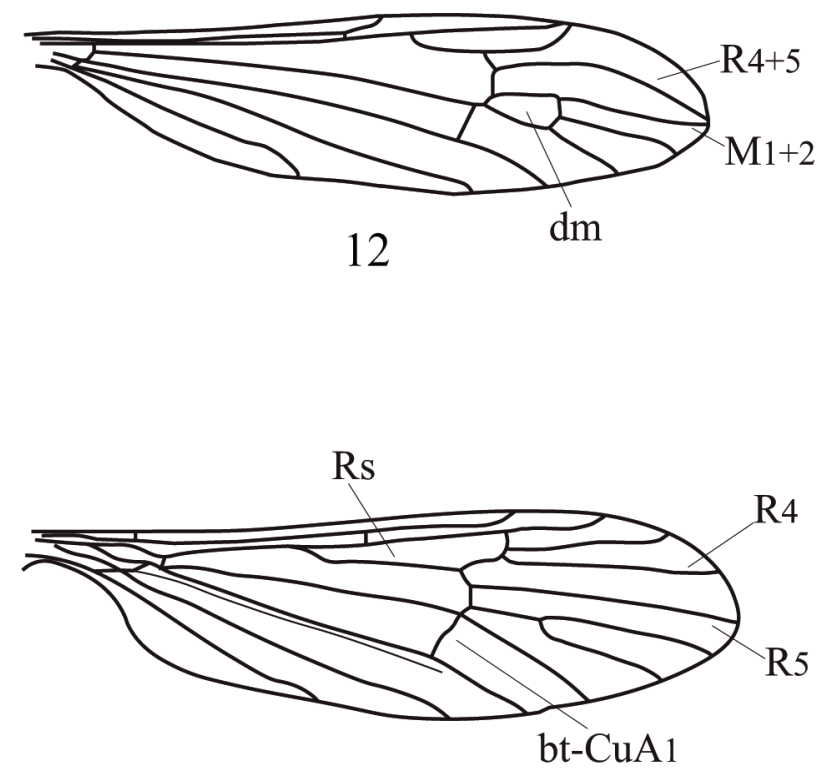

14

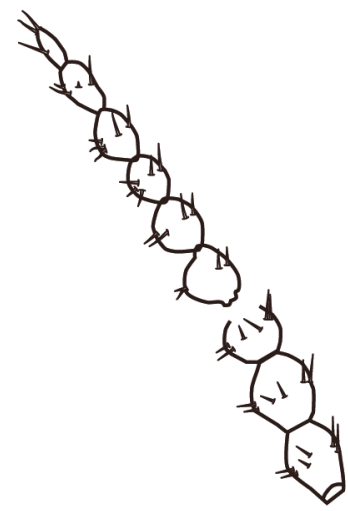

16

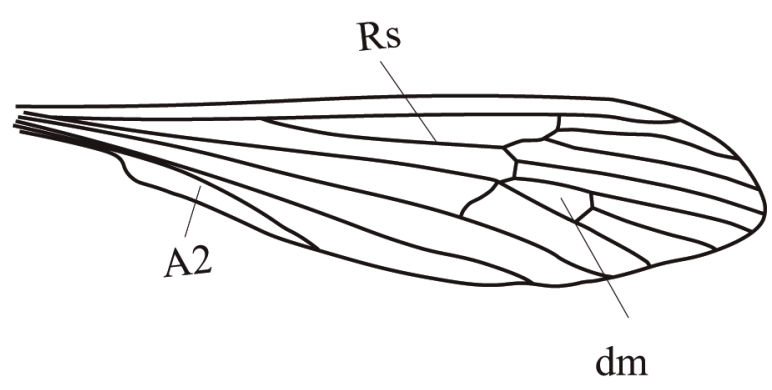

18

Figs 11- 18. Morphological characteres for Tipuloidea genera identification. (11) Gonomyia (Neolipophleps), (12) Gonomyia (Paralipophleps), (13) Molophilus and (14) Ormosia, wings; (15) Rhipidia and (16) Dicranomyia, antennae; (17) Symplecta (Symplecta) and (18) Symplecta (Trimicra), wings. Modified from GelHaus (2009). 
representing around $10 \%$ of Neotropical species (Oosterbroek, 2018). Representatives often display significant morphological variability, confusing species distinctions, so it is common for these to be treated as species complexes (NitTa \& O'Grady, 2008; GoOdman \& O'GradY, 2013; Salmela et al., 2014; STARÝ \& StUBBs, 2015). Species within our Dicranomyia complex were all genetically similar, which suggests that their different morphologies, especially in terms of wing venation, are a morphological plasticity of the group. This is the first report of the genus Ormosia for the Neotropical region, and consequently for Brazil. We expanded the ranges for Polymera inornata and Symplecta cana, with the latter now for both continents of the New World (previously only reported in North America). Symplecta pilipes is a cosmopolitan species, and combined with the American Rhipidia domestica amazonensis, these two species exhibit high densities in Neotropical salt marshes (see also RODRIGUES et al., 2017).

De JoNG et al. (2008) argue that all Tipuloidea species/ subspecies are restricted to determined biogeographic regions, with only a few sharing neighboring regions. Most mtDNACOI sequences found in this work were highly similar to those from Argentina, Costa Rica, Dominican Republic, Ecuador, and Nicaragua (Neotropical region), and different from those from regions such as Canada and U.S.A. (Nearctic region), which corroborates a relatively limited range distribution of these crane fly species, and reinforces the endemic characteristic of this group in the Neotropics. Floyd et al. (2009) alert that using COI sequences for identification of insect species can lead to overestimation of richness. However, we found low intraspecific $(<0.03)$ and high interspecific molecular differences (0.11-0.25) among the sampled insects, indicating that the mtDNA COI region is a useful tool for species distinction in the Tipuloidea. This has also been observed by HEBERT et al. (2004). This molecular marker has been shown to be useful for the identification of other Diptera species with non-conspicuous morphological diagnostic characteristics, such as blackflies (Diptera: Simuliidae; Pramual et al., 2016), mosquitoes (Diptera: Culicidae; Kumar et al., 2007), and sandflies (Diptera: Psychodidae; Nzelu et al., 2015). Gonomyia (Neolipophleps) sp. was the only species with high intraspecific distance (0.03-0.12), because of one or more divergent specimens. This differentiation between specimens was not detected morphologically by wing venation and male genitalia, but could indicate the existence of another Gonomyia (Neolipophleps) species.

The current literature on this superfamily at the Neotropical region is sparse and fragmented, consisting primarily of the original descriptions of C. P. Alexander. In this manner, it becomes necessary a complete review for regional Tipuloidea species. The insertion of new and generically-identified sequences in NCBI is an important step that will provide support for researches using molecular tools for identification and/or phylogenetic studies of Tipuloidea. Additionally, mtDNA COI barcoding is a useful tool for Tipuloidea species identification. This is one of the first works to list and barcode Tipuloidea species from Neotropical salt marshes, decreasing the large gap in information on crane flies at the region, and aiding in future studies aimed towards exploring the life cycles and/or ecology of these insects.

Acknowledgements. We thank H. A. Gastal for help in including the Tipuloidea specimens in the Fundação Zoobotânica do Rio Grande do Sul collection - FZB/RS, Porto Alegre, RS. This work was supported by Coordenação de Aperfeiçoamento de Pessoal de Nível Superior (CAPES).

\section{REFERENCES}

Alexander, C. P. 1912. On the tropical American Rhipidiae (Tipulidae, Dipt.). Bulletin of the Brooklyn Entomological Society 8:6-17.

Alexander, C. P. 1913. A synopsis of part of the Neotropical crane-flies of the subfamily Limnobinae. Proceedings of the United States National Museum 44:481-549.

AleXAnder, C. P. 1962. Contributions to Bolivian entomofauna, XVII. Diptera II. The crane-flies (Tipulidae, Diptera). Zoological Publications College of Munich State 7:9-159.

Alexander, C. P. \& Byers, G. W. 1981. Tipulidae. In: McAlpine, J. F. ed. Manual of Neartic Diptera. Ottawa, Research Banch, Agriculture Canada, p. 153-190.

AlJanABI, S. M. \& Martinez, I. 1997. Universal and rapid salt-extraction of high quality genomic DNA for PCR-based techniques. Nucleic Acids Research 25(22):4692-4693.

Andrew, I. G. 2000. Species diversity in the Trimicra pilipes complex (Diptera: Tipulidae). New Zealand Entomologist 23:3-8.

Autio, O.; Salmela, J. \& Suhonen, J. 2013. Species richness and rarity of crane flies (Diptera, Tipuloidea) in a boreal mire. Journal of Insect Conservation 17:1125-1136.

Baxter, C. V.; Fausch, K. D. \& Sauders, W. C. 2005. Tangled webs: reciprocal flows of invertebrate prey link streams and riparian zones. Freshwater Biology 50:201-220.

Boix, D.; Gascón, S.; SAla, J.; Badosa, A.; Brucet, S.; López-Florez R.; Martinoy, M.; Gifre, J. \& Quintana, X. D. 2008. Patterns of composition and species richness of crustaceans and aquatic insects along environmental gradients in Mediterranean water bodies. Hydrobiologia 597:53-69.

Bolico, C. F.; Oliveira, E. A.; Gantes, M. L.; Dumont, L. F. C.; Carrasco, D. S. \& D'InCAO, F. 2012. Myrmecofauna (Hymenoptera, Formicidae) of the two salt marshes Patos Lagoon Estuary, RS: diversity, fluctuation of the abundance and similarity as indicators of conservation. Entomobrasilis 5(1):11-20.

Britto, V. A. \& Bugoni, L. 2015. The contrasting feeding ecology of great egrets and roseate spoonbills in limnetic and estuarine colonies. Hydrobiologia 744:187-210.

Campos, D. M. A. R.; Silva, A. F.; Sales, N. A.; Oliveira, R. E. M. C. C. \& Pessanha, A. L. M. 2015. Trophic relationships among fish assemblages in a mudflat within Brazilian marine protected area. Brazilian Journal of Oceanography 63(2):135-146.

Chakrabarty, P.; Warren, M.; Page, L. M. \& Balwin, C. C. 2013. GenSeq: An updated nomenclature and ranking for genetic sequences from type and non-type sources. Zookeys 346:29-41.

Contente, R. F.; Steganoni, M. F. \& SPaCh, H. L. 2010. Feeding ecology of the Brazilian silverside Atherinella brasiliensis (Atherinopsidae) in a sub-tropical estuarine ecosystem. Journal of the Marine Biological Association of the United Kingdom 91(6):1197-1205.

Costa, C. S. B. \& Marangoni, J. C. 2010. As comunidades de marismas. In: Seeliger, U. \& Odebrecht, C. eds. O Estuário da Lagoa dos Patos: Um século de transformações. Rio Grande, Universidade Federal do Rio Grande, p. 123-133.

Costa, C. S. B.; Seeliger, U.; Oliveira, C. P. L. \& Mazo, A. M. M. 1997. Distribuição, funções e valores das marismas e pradarias submersas no estuário da Lagoa dos Patos (RS, Brasil). Atlântica 19:65-83.

De Jong, H.; Oosterbroek, P.; Gelhaus, J.; Reusch, H. \& Young, C. 2008. Global diversity of craneflies (Insecta, Diptera: Tipulidea or Tipulidae sensu lato) in freshwater. Hydrobiologia 595:457-467.

D'IncaO, F.; Ruffino, M. L.; Silva, K. B. \& Braga, A. C. 1992. Responses of Chasmagnathus granulata Dana (Decapoda: Grapsidae) to salt-marsh 
environmental variations. Journal of Experimental Marine Biology and Ecology 161:179-188.

Dummel, K.; Oliveira, E. A.; Zardo, C. M. L. \& D'Incao, F. 2011. Changes in abundance, ecology diversity and similarity of Coleoptera (Insecta) between sandbank and salt sarsh of the estuary of the Patos Lagoon, Rio Grande, RS. Entomobrasilis 4(2):39-44.

Floyd, R. M.; WilsON, J. J. \& HeBERT, P. D. 2009. DNA barcodes and insect biodiversity. In: Foottit, R. G. \& ADLER, P. H. Insect Biodiversity: Science and Society. Oxford, Wiley-Blackwell Publishing, p. 417-431.

Folmer, O.; Black, M.; Hoeh, W.; Lutz, R. \& Vrijenhoek, R. 1994. DNA primers for amplification of mitochondrial cytochrome c oxidase subunit I from diverse metazoan invertebrates. Molecular Marine Biology and Biotechnology 3(5):294-299.

Gantes, M. L.; Carrasco, D. S. \& D'Incao, F. 2013. First record of Lepidoptera in southern Brazilian salt marshes. Entomobrasilis 6(2):160-161.

Gelhaus, J. K. 2009. Tipulidae (Crane flies, Tipúlidos). In: B.V. Brown; Borkent, A.; Cumming, J. M.; Wood, D. M.; Woodley, N. E. \& Zumbado, M. eds. Manual of Central American Diptera, vol. 1, Ottawa, National Research Council of Canada, p. 193-236.

Giberson, D. J.; Bilyu, B. \& Burgess, N. 2001. Species diversity and emergence patterns of nematocerous flies (Insecta: Diptera) from three coastal salt marshes in Prince Edward insland, Canada. Estuaries 24:862-874.

Goodman, K. R. \& O'Grady, P. 2013. Molecular phylogeny and biogeography of the Hawaiian craneflies Dicranomyia (Diptera: Limoniidae). PlosOne 8(9):1-10.

HALL, T. A. 1999. BioEdit: a user-friendly biological sequence alignment editor and analysis program for Windows 95/98/NT. Nucleic Acids Symposium Series 41:95-98.

HaRTLEY, J. L. \& Bowen, H. 1996. PEG precipitation for selective removal of small DNA fragments. In: CUPO, D. ed. CFLP mutation detection. Focus $28 \mathrm{p}$

Hebert, P. D. N.; Penton, E. H.; Burns, D. H. \& Hallwach, W. 2004. Ten species in one: DNA barcoding reveals cryptic species in the neotropical skipper butterfly Astrapes fulgerator. Proceedings of the National Academy of Sciences of the United States of America 101:14812-14817.

Kumar, N. P.; Rajavel, A. R.; Natarajan, R. \& Jambulingam, P. 2007. DNA barcodes can distinguish species of Indian mosquitoes (Diptera: Culicidae). Journal of Medical Entomology 44(1):1-7.

Lenat, D. R. \& ReSh, V. H. 2001. Taxonomy and stream ecology - The benefits of genus- and species-level identifications. Journal of the North American Benthological Society 20(2):287-298.

MACKENZIE, R. A. 2005. Spatial and temporal patterns in insect emergence from a southern Maine salt marsh. The American Midland Naturalist 153:257-269.

Mackenzie, R. A.; Dionne, M.; Miller, J.; Haas, M. \& Morgan, P. A. 2015. Community structure and abundance of benthic infaunal invertebrates in Maine fringing marsh ecosystems. Estuaries and Coasts 38:1317-1334.

MCAlPINE, J. F. 1981. Morphology and terminology — adults. In: MCAlPINE, J. F.; Peteron, B.V.; Shewell, G. E.; Teskey, H. J.; Vockeroth, J.R.
\& Wood, D. M. eds. Manual of Nearctic Diptera, vol. 1. , Ottawa, Biosystematics Research Institute, p. 9-63. (Monograph no. 27).

Nitta, J. H. \& O'Grady, P. M. 2008. Mitochondrial phylogeny of the endemic Hawaiian craneflies (Diptera, Limoniidae, Dicranomyia): Implications for biogeography and species formation. Molecular Phylogenetics and Evolution 46(3):1182-1190.

Nzelu, C. O.; CÁceres, A. G.; Arruátegui-Jiménez, M. J.; Lañas-Rosas, M. F.; Yanez-Trujillano, H. H.; Luna-Caipo, D. V.; HolguínMauricci, C. E.; Katakura, K.; Hashiguchi, Y. \& Kato, H. 2015. DNA barcoding for identification of sand fly species (Diptera: Psychodidae) from leishmaniasis-endemic areas of Peru. Acta Tropica 145:45-51.

Oosterbroek, P. 2018. Catalogue of the Craneflies of the World (Insecta, Diptera, Nematocera, Tipuloidea). Available from: $<$ http://ip30.eti. uva.nl/ccw/>. Accessed Aug. 2018.

Pilipenko, V. E.; Salmela, J. \& Vesterinen, E. J. 2012. Description and DNA barcoding of Tipula (Pterelachisus) recondita sp. n. from the Palaearctic region (Diptera, Tipulidae). Zookeys 192:51-65.

Pramual, P.; Thaijarern, J. \& Wongpakam, K. 2016. DNA barcoding of human-biting black flies (Diptera: Simuliidae) in Thailand. Acta Tropica 164:33-40.

Ribeiro, G. C.; Lamas, C. J. M. \& Azevedo, L. N. S. 2007. A catalogue of the types of Limoniidae and Tipulidae (Diptera: Tipulomorpha) in the collection of the Museu de Zoologia da Universidade de São Paulo, Brazil. Zootaxa 1497:1-22.

Ribeiro, G. C. \& Santos, D. 2016. Families Tipulidae and Limoniidae. In: Wolff, M.; Nihei, S. S. \& Carvalho, C. J. B. De. eds. Catalogue of Diptera of Colombia. Zootaxa 4122(1):73-97.

Rodrigues, L.; Carrasco, D. \& Proietti, M. 2017. Spatio-temporal structure and influence of environmental parameters on the Tipuloidea (Insecta: Diptera) assemblage of Neotropical salt marshes. Estuarine, Coastal and Shelf Science 197:1-9.

Rogers, J. S. 1932. On the biology of Limonia (Dicranomyia) floridana (Osten Sacken). Florida Entomologist 15:65-70.

Salmela, J.; Kaunisto, K. M. \& Vahtera, V. 2014. Unveiling of a cryptic Dicranomyia (Idiopyga) from northern Finland using integrative approach (Diptera, Limoniidae). Biodiversity Data Journal 2:1-27.

SAmbrooK, J.; Fritsch, E. F. \& Maniatis, T. 1989. Molecular cloning: a laboratory manual. New York, Cold Spring Laboratory. 545p.

Silberbush, A.; Blaustein, L. \& Margalith, Y. 2005. Influence of salinity concentration on aquatic insect community structure: a mesocosm experiment in the Dead Sea Basin Region. Hydrobiologia 548:1-10.

Starý, J. \& Brodo, F. 2009. Artic species of subgenus Symplecta sensu stricto (Diptera: Limoniidae). Entomological Society of Canada 141:1-30.

Starý, J. \& StubBs, A. E. 2015. Five species under Dicranomyia (Dicranomyia) mitis (Meigen, 1830) (Diptera, Limoniidae). Zootaxa 3964(3):321-334.

Stevens, P. W.; Fox, S. L. \& Montague, C. L. 2006. The interplay between mangroves and saltmarshes at the transition between temperate and subtropical climate in Florida. Wetlands Ecology and Management 14:435-444.

Williams, D. D. \& Williams, N. E. 1998. Aquatic insects in and estuarine environment: densities, distribution and salinity tolerance. Freshwater Biology 39:411-421. 